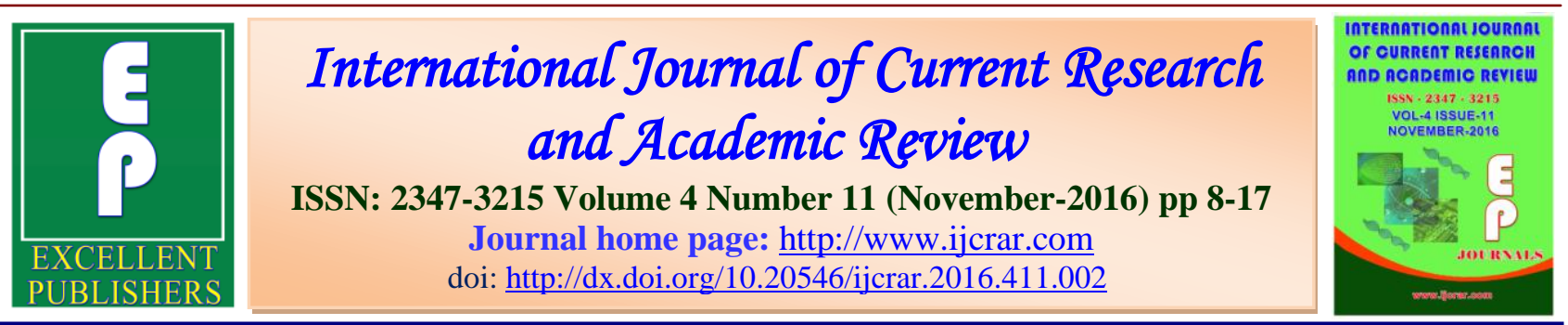

\title{
Protective Effects of Gramine on Cell Surface Integrity and Status of Lipid Profile during DMBA induced Oral Carcinogenesis
}

\author{
Ramu Arun Kumar, Kathiresan Suresh*, Ramadoss Hemavardhini and Nallu Anandhi \\ Department of Biochemistry and Biotechnology, Faculty of Science, Annamalai University, \\ Annamalainagar- 608002, Tamilnadu, India \\ *Corresponding author
}

\begin{tabular}{|c|c|}
\hline KEYWORDS & 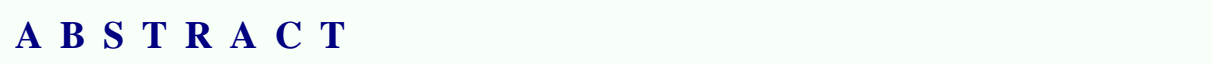 \\
\hline $\begin{array}{l}\text { Oral cancer, } \\
\text { DMBA, } \\
\text { Alkaloid, } \\
\text { Glycoconjugates, } \\
\text { Lipid Profile. }\end{array}$ & $\begin{array}{l}\text { Gramine is a pungent alkaloid significantly found in barley (Hordeum } \\
\text { vulgare), that have antioxidant and chemopreventive properties owing their } \\
\text { indoles nature. The present study aimed to examine the protective effect of } \\
\text { gramine on cell surface glycoconjugates and lipid profile status against } 7,12 \text { - } \\
\text { dimethylbenz[a]anthracene (DMBA) induced hamster buccal pouch } \\
\text { carcinogenesis. Oral squamous cell carcinoma was induced in male Syrian } \\
\text { golden hamster's buccal pouch by painting with } 0.5 \% \text { DMBA in liquid } \\
\text { paraffin at three times a week of } 16 \text { weeks. We observed malignancy with } \\
\text { marked abnormalities of glycoconjugates (protein bound hexose, hexosamine, } \\
\text { sialic acid and fucose), lipid (Total cholesterol, Phospholipids, Free fatty acid } \\
\text { and C/P ratio) status in tumor bearing hamsters. Oral administration of } \\
\text { gramine ( } 80 \mathrm{mg} / \mathrm{kg} \text { b.wt), to DMBA painted cancer animals significantly } \\
\text { modulate the levels of cell surface glycoconjugates and lipid profiles activity } \\
\text { to near normal range. Present study suggested that gramine has potent } \\
\text { chemopreventive efficacy on protected the abnormalities on cell surface } \\
\text { glycoconjugates and lipid status against oral cancer. }\end{array}$ \\
\hline
\end{tabular}

\section{Introduction}

Oral squamous cell carcinoma is the fifth most major neoplasm in the worldwide and is the leading cancer among males in Indian subcontinent accounting for $40-50 \%$ of all cancers (Gaur et al., 2011). Utilization tobacco, betel quid and liquor are major risk factor associated with development of oral SCCs (Attolini and Michor, 2009). DMBA are potent poly aromatic hydrocarbon found 40-100ng per cigarette, which recognized as a causal agent of oral cancer (Lee et al., 2002). Glycoproteins are well suited as primary factor for intermediating cell surface functions like cellular bond, cell to cell recognition (Casper et al., 1999). Samples of oral cancer patients and DMBA painted tumor bearing laboratory animals were identified when aberrant expression of 
hexosamine, protein-bound hexoses, lipidbound sialic acid, total sialic acid, and fucose which demonstrating their helpfulness in judgment or screening treatment (Bose et al., 2013).

The hexose and hexosamines are an essential role in the body being present in the ground substance of every single connective tissue as parts of mucopolysaccharides and mucoproteins (Blumenkrantz and AsboeHansen, 1976). Strangely, increased hexosamine exhibits the dynamic development and proliferation of tumor cells (West et al., 1985). Therefore, hexosamine is a target for chemoprevention of different tumors including oral squamous cell carcinomas. Fucose is a typical monosaccharide residues those are present in the terminal chains of oligosaccharides of membrane bound or secreted molecules as it can slow down the growth of cancer cells (Walz et al., 1990; Patel et al., 1994). Sialic acid is a strong electronegative charge acidic sugar at physiological conditions that is observed at the external ends of cell surface glycan chain (Varki and Varki, 2007). Abnormally increased sialic acid content was correlated with cell attachment and migration thus contributing to the migratory and invasive phenotype of the cells (Seales et al., 2005). However, the high expression of sialic acids can shield tumor cells from apoptosis and has been suggested to confer resistance to tumor therapy (Bull et al., 2014).

Lipids play an important role in several cellular processes and altered levels of lipids affect the structure and function of the cell. Free radical induced lipid peroxidation is regarded as one of the basic mechanisms for cellular damage and therefore, the extent of tissue damage can be monitored by measuring the concentration of plasma lipid peroxides (Hail et al., 2008). Abnormalities in cholesterol phospholipid ratio lead to affects the physio-chemical properties of the cell, contributing to malignant transformation (Fliesler et al., 1995). Several studies also reveal lipid alterations in certain human pathogenesis. It is a conceivable that molecules capable of interacting with membrane lipids may induce modifications in membrane composition, protein function or gene expression and reversion of the pathological state (Bartsch and Nair, 2000).

The indole alkaloid, gramine (3[Dimethylaminomethyl]indole) is an active constituent of several cereals and it significantly occurs in Hordeum vulgare. Numerous studies showed diverse pharmacological and biochemical impacts of gramine, such as, vasorelaxation, blood pressure elevation, bronchial asthma and antioxidant properties (Iwata et al., 2001). It additionally assumes important roles for the metabolite action of amino acid in living organism (Ke et al., 2012). Present study was designed to focus the protective effect of gramine on cell surface glycoproteins integrity and status of lipid profile during DMBA induced oral carcinogenesis in golden Syrian hamsters.

\section{Materials and Methods}

\section{Chemicals}

DMBA and gramine were bought from Sigma-Aldrich Chemical Pvt. Ltd., Bangalore, India. All other chemicals used were of analytical grade, obtained from Himedia Laboratories, Mumbai, India.

\section{Animals}

Male golden Syrian hamsters, 8-10 weeks and weighing 80-120 g, were obtained from the National Institute of Nutrition, Hyderabad, India and were maintained in the Central Animal House, Rajah Muthaiah 
Medical College and Hospital, Annamalai University. The animals were housed in polypropylene cages at proper temperatures $\left(27 \pm 2^{\circ} \mathrm{C}\right)$ with relative humidity $55 \pm 5 \%$, light: dark cycle is almost $12: 12 \mathrm{~h}$ and provided standard pellet diet and water ad libitum. Hamsters were maintained in accordance (Proposal No. 946) with the guidelines of ethical committee for animal care of Annamalai University (Register number 160/1999/CPCSEA) in accordance with Indian National law on animal care and use.

\section{Experimental design}

A total number of 40 hamsters were randomized into four groups and each group contained 10 hamsters. Group I animals served as the control and were treated with liquid paraffin alone. Group II hamsters were painted with $0.5 \%$ DMBA in liquid paraffin three times a week on their left buccal pouches. Group III animals were treated with DMBA and received in addition oral administration of gramine at a dose of $80 \mathrm{mg} / \mathrm{kg}$ b.wt alternate days to DMBA painting. Group IV animals received oral administration of gramine only. The experiment was terminated at the end of $16^{\text {th }}$ week and all animals were sacrificed and blood samples were collected into heparinized tubes. The plasma was separated by centrifugation at $3000 \mathrm{rpm}$ for 15 mins. After plasma separation, the erythrocyte membrane was prepared by the method of Dodge et al., (1963) modified by Quist (1980).

\section{Preparation of Tissue Homogenate}

Tissue samples from animals were washed with ice cold saline and dried between folds of filter paper, weighed and homogenized using appropriate buffer (appropriate buffer of concerned parameter [TBARS-0.025M Tris-Hcl buffer, $\mathrm{pH}$ 7.5; GSH and GPx- 0.4
M phosphate buffer, $\mathrm{pH}$ - 7.0; SOD - 0.025 $\mathrm{M}$ sodium pyrophosphate buffer, $\mathrm{pH} 8.3$; CAT - 0.01 M phosphate buffer, $\mathrm{pH} 7.0]$ ) in an all-glass homogenizer with teflon pestle. The homogenate was centrifuged at 1500 rpm for 5 minutes and the supernatant was then used for the biochemical estimations.

\section{Biochemical studies}

Protein bound hexose in plasma were estimated by method of Niebes (1972). Plasma protein bound hexosamine were determined by method of Wagner (2008). The total sialic acid in plasma and defatted buccal mucosa tissues were estimated by the method of Warren (1959). Plasma lipid bound sialic acid concentration was determined by the procedure of Katopodis and Stock (1980). Fucose in plasma and buccal mucosa tissue were determined by the method of Dische and Shettles (1948). Total cholesterol was estimated by the method of Parekh and Jung (1970). Phospholipids were estimated in plasma and erythrocyte membrane by the method of Zilversmit and Davis (1950). Free Fatty Acids were estimated by the method of Falholf et al., (1973). Triglycerides were estimated by the method of Foster and Dunn (1973).

\section{Statistical analysis}

The data were expressed as mean \pm S.D with six animals in each group. Values were analysed using SPSS/15.0 software. Hypothesis testing methods were included with analysis of variance [ANOVA] followed by least significance difference [LSD]. $\mathrm{P}$ values of $>0.05$ were considered statistically significant.

\section{Results and Discussion}

Table 1 Shows the levels of glycoconjugates (Protein bound hexose, Protein bound hexosamine, Total sialic acid, Lipid bound 
sialic acid and Fucose,) in the plasma of control and experimental animals in each group. The levels of glycoconjugates in the plasma were significantly increased in DMBA alone painted animals as compared to control animals. Oral administration of gramine ( 80 $\mathrm{mg} / \mathrm{kg} \mathrm{bw}$ ) on DMBA painted animals brought back the levels of above mentioned abnormal glycoconjugates to near normal range. No significant differences were noticed in the levels of plasma glycoconjugates in gramine alone treated animals as compared to control animals.

Table 2 Shows the levels of glycoconjugates (Protein bound hexose, Protein bound hexosamine, Total sialicacid and Fucose) in the erythrocyte membrane and buccal mucosa of control and experimental animals in each group. The levels of glycoconjugates in erythrocyte membrane were significantly decreased and buccal mucosa was significantly increased in DMBA alone painted animals as compared to control animals. Oral administration of gramine (80 $\mathrm{mg} / \mathrm{kg}$ b.wt) against DMBA painted animals restored the levels of above mentioned glycoconjugates to near normal range. No significant differences were noticed in the levels of erythrocyte membrane and buccal mucosa glycoconjugates in gramine alone treated animals as compared to control animals.

Table 3 Shows the levels of lipid profile (Total cholesterol, Phospholipids, Free fatty acid, Triglyceride and $\mathrm{C} / \mathrm{P}$ ratio) in the plasma and buccal mucosa of control and experimental animals in each group. The total cholesterol, free fatty acid and $\mathrm{C} / \mathrm{P}$ ratio levels were increased whereas phospholipids and triglyceride levels were decreased in plasma and buccal mucosa of DMBA alone painted animals as compared to control animals. Oral administration of gramine $(80 \mathrm{mg} / \mathrm{kg} \mathrm{b.wt})$ restored the status of cholesterol, phospholipids, free fatty acid, triglyceride and $\mathrm{C} / \mathrm{P}$ ratio to near normal. No significant differences were noticed in gramine alone treated animals as compared to control animals.

Table 4 shows the levels of lipid profiles (Total cholesterol, Phospholipids, Free fatty acid and $\mathrm{C} / \mathrm{P}$ ratio) in the erythrocyte membrane of control and experimental animals in each group. The levels of total cholesterol, free fatty acid and $\mathrm{C} / \mathrm{P}$ ratio were increased in erythrocyte membrane of DMBA alone painted animals as compared to control animals. Oral administration of gramine ( 80 $\mathrm{mg} / \mathrm{kg} \mathrm{b.wt)} \mathrm{treatment} \mathrm{against} \mathrm{DMBA} \mathrm{painted}$ animals brought back the levels of total cholesterol, phospholipids, free fatty acid and $\mathrm{C} / \mathrm{P}$ ratio to near normal range. No significant differences were observed in gramine alone treated animals as compared to control animals.

Extracellular matrix plays an essential role in the surface properties of the cells such as regulating cell proliferation, adhesion and migration to induce cell differentiation and death (Hynes, 2009). Experimental studies shows that oral cancer alters the hexosamine, hexoses, sialic acid, fucose, phospholipids, glycolipids and cholesterol in extracellular matrix, which causes upregulates proliferation, evades apoptosis, angiogenesis and metastasis (Kumar et al., 2015; Taqi, 2015; Isozaki et al., 2014; Bayer et al., 2013). Therefore, novel agent that capable to down-regulate the aberrant expressions of glycoconjugates and lipids of oral cancer would be great benefit for patients. Now-a-days, phytochemicals from edible plants received much attention as chemopreventive agents for defending cells and tissues against various carcinogens. Present study, we examined the anticancer efficacy of gramine, a natural indole alkaloid and its mechanism of action on 
modulates glycoconjugates, lipids profiles in 7,12-dimethylbenz[a]anthracene (DMBA) induced hamster buccal pouch (HBP) cancer model.

The malignant transformation is usually associated with molecular changes such glycosylation of glycoproteins and glycolipids. Aberrant glycosylation can have an effect on macromolecule function such as modulates protein stability and solubility thereby induces malignant transformation in oral epithelial tissue (Stowell et al., 2015). Fernandez et al., (1997) noted that increased fucose content in tumor tissue and plasma is probably due to increased turnover of malignant cells with subsequent shedding into circulation. Goodarzi et al., (2005) reported that marked elevation of total sialic acid and lipid bound sialic acid in plasma are found to reflect tumor burden. It is clear from this study that, DMBA induced tumor bearing animals that exhibits elevated levels of hexose, hexoseamine and sialic acid expression in plasma, whereas decreased in erythrocyte membrane (Suresh et al., 2007). Hence, aberrant activations of these glycoproteins represent an effective target for treatment of oral cancer. Present study, oral administration of gramine $(80 \mathrm{mg} / \mathrm{kg} \mathrm{bw})$ restores the altered status of hexose, hexose amine and sialic acid expression in the DMBA induced hamster buccal pouch carcinoma. Similar with our study, Sindhu and Manoharan (2010) reported that alkaloid berberine reduces plasma and tissue glycoprotein levels in DMBA induced oral carcinogenesis. Therefore, reduction within the status of glycoprotein expression indicates gramine has the ability to suppress malignant transformation.

The abnormalities of lipids have been implicated proliferation and progression of cancer cells. In particular, changed level of phospholipid and cholesterol malformed the fluidity of lipid membranes thereby upregulated progression of cancer (Swierczynski et al., 2014). Raised plasma fatty acid concentration elevates the liver in the transformation of some unsaturated fats into phospholipids and cholesterol.

Table.1 The levels of glycoconjugates in the plasma of control and experimental animals in each group

\begin{tabular}{lcccc}
\hline \multicolumn{1}{c}{$\begin{array}{c}\text { Parameters/ } \\
\text { Groups }\end{array}$} & Control & DMBA & $\begin{array}{c}\text { DMBA + } \\
\text { Gramine } \\
(80 \mathrm{mg} / \mathrm{kg} \mathrm{bw})\end{array}$ & $\begin{array}{c}\text { Gramine } \\
\text { alone }\end{array}$ \\
\hline \hline & & & & \\
$\begin{array}{l}\text { Protein bound hexose } \\
{[\mathrm{mg} / \mathrm{dl}]}\end{array}$ & $88.36 \pm 8.91^{\mathrm{a}}$ & $131.62 \pm 13.09^{\mathrm{b}}$ & $99.44 \pm 10.39^{\mathrm{c}}$ & $90.13 \pm 9.05^{\mathrm{a}}$ \\
$\begin{array}{l}\text { Protein bound hexosamine } \\
{[\mathrm{mg} / \mathrm{dl}]}\end{array}$ & $72.61 \pm 7.32^{\mathrm{a}}$ & $117.45 \pm 11.53^{\mathrm{b}}$ & $84.11 \pm 8.72^{\mathrm{c}}$ & $73.18 \pm 7.56^{\mathrm{a}}$ \\
$\begin{array}{l}\text { Total Sialic acid } \quad[\mathrm{mg} / \mathrm{dl}] \\
\text { Lipid bound sialic acid }[\mathrm{mg} / \mathrm{dl}]\end{array}$ & $45.73 \pm 4.67^{\mathrm{a}}$ & $74.82 \pm 7.53^{\mathrm{b}}$ & $57.94 \pm 5.77^{\mathrm{c}}$ & $46.43 \pm 4.66^{\mathrm{a}}$ \\
$\begin{array}{l}\text { Fucose } \\
{[\mathrm{mg} / \mathrm{dl}]}\end{array}$ & $11.46 \pm 1.17^{\mathrm{a}}$ & $30.95 \pm 3.03^{\mathrm{b}}$ & $19.63 \pm 1.94^{\mathrm{c}}$ & $12.86 \pm 1.29^{\mathrm{a}}$ \\
\hline \hline
\end{tabular}

Values are expressed as the mean \pm SD for 10 hamsters in each group. Values that are not sharing a common superscript letter in the same column differ significantly at $\mathrm{p}<0.05[\mathrm{DMRT}]$. 
Int.J.Curr.Res.Aca.Rev.2016; 4(11): 8-17

Table.2 The levels of glycoconjugates in the erythrocyte membrane and buccal mucosa of control and experimental animals in each group

\begin{tabular}{|c|c|c|c|c|}
\hline $\begin{array}{c}\text { Parameters/ } \\
\text { Groups }\end{array}$ & Control & 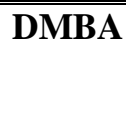 & $\begin{array}{c}\text { DMBA + } \\
\text { Gramine } \\
(80 \mathrm{mg} / \mathrm{kg} \mathrm{bw})\end{array}$ & " Gramine alone \\
\hline
\end{tabular}

\section{Erythrocyte Membrane}

Protein bound hexose

[ $\mu \mathrm{g} / \mathrm{mg}$ protein]

Protein bound hexosamine

$[\mu \mathrm{g} / \mathrm{mg}$ protein]

Total sialicacid

[ $\mu \mathrm{g} / \mathrm{mg}$ protein]

Protein bound hexose
[mg/g tissue]
Total sialicacid
[mg/g tissue]
Fucose
$[\mathrm{mg} / \mathrm{g}$ tissue]

\begin{abstract}
$126.15 \pm 12.63^{\mathrm{a}}$
\end{abstract}
$87.50 \pm 8.71^{\mathrm{a}}$

$35.43 \pm 3.57^{\mathrm{a}}$

$109.74 \pm 10.98^{\mathrm{a}}$

$17.13 \pm 1.80^{\mathrm{a}}$

$12.64 \pm 1.27^{\mathrm{a}}$

$87.52 \pm 8.81^{\mathrm{b}}$

$113.21 \pm 11.97^{\mathrm{c}}$

$55.40 \pm 5.62^{\mathrm{b}}$

$74.27 \pm 7.50^{\mathrm{c}}$

$30.96 \pm 3.11^{\mathrm{c}}$

$19.14 \pm 2.02^{\mathrm{b}}$

\section{Buccal Mucosa}

Values are expressed as the mean \pm SD for 10 hamsters in each group. Values that are not sharing a common superscript letter in the same column differ significantly at $p<0.05$ [DMRT].

Table.3 The levels of lipid profile in the plasma and buccal mucosa of control and experimental animals in each group

\begin{tabular}{|c|c|c|c|c|}
\hline $\begin{array}{l}\text { Parameters/ } \\
\text { Groups }\end{array}$ & Control & DMBA & $\begin{array}{c}\text { DMBA + Gramine } \\
(80 \mathrm{mg} / \mathrm{kg} \mathrm{bw})\end{array}$ & Gramine alone \\
\hline \multicolumn{5}{|c|}{ Plasma } \\
\hline $\begin{array}{l}\text { Total cholesterol } \\
{[\mathrm{mg} / \mathrm{dl}]}\end{array}$ & $97.10 \pm 9.69^{\mathrm{a}}$ & $131.69 \pm 13.17^{\mathrm{b}}$ & $108.82 \pm 10.81^{\mathrm{c}}$ & $96.13 \pm 9.61^{\mathrm{a}}$ \\
\hline $\begin{array}{l}\text { Phospholipids } \\
{[\mathrm{mg} / \mathrm{dl}]}\end{array}$ & $130.49 \pm 13.05^{\mathrm{a}}$ & $93.62 \pm 9.41^{\mathrm{b}}$ & $119.18 \pm 12.10^{c}$ & $129.56 \pm 13.07^{\mathrm{a}}$ \\
\hline $\begin{array}{l}\text { Free fatty acid } \\
{[\mathrm{mg} / \mathrm{dl}]}\end{array}$ & $8.96 \pm 0.97^{\mathrm{a}}$ & $16.71 \pm 1.68^{\mathrm{b}}$ & $10.96 \pm 1.03^{\mathrm{c}}$ & $9.21 \pm 0.93^{\mathrm{a}}$ \\
\hline $\begin{array}{l}\text { Triglyceride } \\
{[\mathrm{mg} / \mathrm{dl}]}\end{array}$ & $85.29 \pm 8.64^{\mathrm{a}}$ & $51.89 \pm 5.20^{\mathrm{b}}$ & $76.13 \pm 7.70^{\mathrm{c}}$ & $84.53 \pm 8.49^{\mathrm{a}}$ \\
\hline C/P Ratio & $0.87 \pm 0.09^{\mathrm{a}}$ & $1.45 \pm 0.16^{\mathrm{b}}$ & $1.03 \pm 0.10^{c}$ & $0.89 \pm 0.09^{\mathrm{a}}$ \\
\hline \multicolumn{5}{|c|}{ Buccal Mucosa } \\
\hline $\begin{array}{l}\text { Total cholesterol } \\
\text { [ } \mathrm{g} / \mathrm{mg} \text { tissue }]\end{array}$ & $4.21 \pm 0.44^{\mathrm{a}}$ & $7.95 \pm 0.80^{\mathrm{b}}$ & $5.17 \pm 0.52^{c}$ & $4.36 \pm 0.42^{\mathrm{a}}$ \\
\hline $\begin{array}{l}\text { Phospholipid } \\
{[\mu \mathrm{g} / \mathrm{mg} \text { tissue }]}\end{array}$ & $14.71 \pm 1.50^{\mathrm{a}}$ & $8.45 \pm 0.91^{b}$ & $11.85 \pm 1.12^{\mathrm{c}}$ & $15.62 \pm 1.60^{\mathrm{a}}$ \\
\hline $\begin{array}{l}\text { Free fatty acid } \\
{[\mu \mathrm{g} / \mathrm{mg} \text { tissue }]}\end{array}$ & $15.29 \pm 1.56^{\mathrm{a}}$ & $7.94 \pm 0.83^{b}$ & $13.07 \pm 1.40^{\mathrm{c}}$ & $15.93 \pm 1.60^{\mathrm{a}}$ \\
\hline C/P Ratio & $0.37 \pm 0.04^{\mathrm{a}}$ & $0.89 \pm 0.09^{\mathrm{b}}$ & $0.43 \pm 0.05^{\mathrm{c}}$ & $0.38 \pm 0.04^{\mathrm{a}}$ \\
\hline
\end{tabular}

Values are expressed as the mean \pm SD for 6 hamsters in each group. Values that are not sharing a common superscript letter in the same column differ significantly at $\mathrm{p}<0.05$ [DMRT]. 
Table.4 The levels of lipid profile in the erythrocyte membrane of control and experimental animals in each group

\begin{tabular}{lcccc}
\hline \hline \multicolumn{1}{c}{$\begin{array}{c}\text { Parameters/ } \\
\text { Groups }\end{array}$} & Control & DMBA & $\begin{array}{c}\text { DMBA + } \\
\text { Gramine } \\
(80 \mathrm{mg} / \mathrm{kg} \mathrm{bw})\end{array}$ & $\begin{array}{c}\text { Gramine } \\
\text { alone }\end{array}$ \\
\hline \hline $\begin{array}{l}\text { Total cholesterol }[\mu \mathrm{g} / \mathrm{mg} \\
\text { protein] }\end{array}$ & $118.63 \pm 11.92^{\mathrm{a}}$ & $159.74 \pm 16.27^{\mathrm{b}}$ & $127.13 \pm 12.60^{\mathrm{c}}$ & $119.62 \pm 12.07^{\mathrm{a}}$ \\
$\begin{array}{l}\text { Phospholipids } \\
{[\mu \mathrm{g} / \mathrm{mg} \text { protein] }}\end{array}$ & $245.63 \pm 24.67^{\mathrm{a}}$ & $193.27 \pm 19.40^{\mathrm{b}}$ & $232.19 \pm 23.15^{\mathrm{c}}$ & $244.87 \pm 24.51^{\mathrm{a}}$ \\
$\begin{array}{l}\text { Free fatty acid } \\
{[\mu \mathrm{g} / \mathrm{mg} \text { protein] }}\end{array}$ & $13.95 \pm 1.41^{\mathrm{a}}$ & $27.65 \pm 2.81^{\mathrm{b}}$ & $18.94 \pm 2.02^{\mathrm{c}}$ & $14.20 \pm 1.47^{\mathrm{a}}$ \\
$\mathbf{C} / \mathbf{P}$ ratio & $0.53 \pm 0.05^{\mathrm{a}}$ & $1.08 \pm 0.11^{\mathrm{b}}$ & $0.64 \pm 0.07^{\mathrm{c}}$ & $0.54 \pm 0.05^{\mathrm{a}}$ \\
\hline \hline
\end{tabular}

Values are expressed as the mean \pm SD for 10 hamsters in each group. Values that are not sharing a common superscript letter in the same column differ significantly at $p<0.05$ [DMRT].

However, decrease in plasma triglycerides indicates an increase in lipolysis during carcinogenesis (Rajkamal et al., 2010). Increase in $\mathrm{C} / \mathrm{P}$ ratio in plasma and tumor tissue has been well documented in several types of cancerous conditions. Hence agents that recover these abnormal lipid statuses in the cell membrane have been successfully used in treating of oral cancer. In the present study it was observed the aberrant levels of total cholesterol, triglycerides, phospholipids, free fatty acids and $\mathrm{C} / \mathrm{P}$ ratio in $\mathrm{DMBA}$ induced tumor bearing hamsters. Oral administration of gramine $(80 \mathrm{mg} / \mathrm{kg}$ bw $)$ significantly normalized the levels of lipid profile and improved the integrity of cell structure and function.

A similar finding were obtained from anticancer agent taxol that modulate these lipid abnormalities on 7, 12dimethylbenz[a]anthracene induced mammary gland carcinogenesis in Sprague Dawley rats (Gokul Raj et al., 2015). Thus, gramine significantly normalized the levels of lipid profile leads to improve the integrity of cell structure and function against DMBA induced HBP carcinomas.
Taken together, these data indicate that gramine regulate altered membrane glycoprotein and lipid profiles and structure in tumor bearing animals. Further studies are warranted to elucidate the mechanistic pathway on effect of gramine in DMBA affected hamster buccal pouch carcinogenesis by molecular signalling pathway. These finding may clarified that gramine has ability to suppress malignancy through modulating cell membrane abnormalities thereby suppressing oral cancer.

Conflict of interests: This research has no conflict of interest

\section{Acknowledgement}

Financial assistance from Indian Council of Medic Research [ICMR], New Delhi, is gratefully acknowledged (45/26/2012/PHABMS dated 16-1-2013).

\section{References}

Attolini, C.S., Michor, F.2009. Evolutionary theory of cancer. Ann. N.Y. Acad. Sci., 1168: 23-51. 
Int.J.Curr.Res.Aca.Rev.2016; 4(11): 8-17

Bartsch, H., Nair, J. 2000. Ultrasensitive and specific detection methods for exocylic DNA adducts: markers for lipid peroxidation and oxidative stress. Toxicol., 153: 105-114.

Bayer, N.B., Schubert, U., Senturk, Z., Rudloff, S., Frank, S., Hausmann, H., Geyer, H., Geyer, R., Preissner, K.T., Galuska, S.P. 2013 Feb 26.Artificial and natural sialic acid precursors influence the angiogenic capacity of human umbilical vein endothelial cells. Mol., 18(3): 2571-2586.

Blumenkrantz, N., Asboe-Hansen, G. 1976.An assay for total hexosamine and a differential assay for glucosamine and galactosamine. Clin Biochem., 9: 269-274.

Bose, SC., Gokhale, P.V., Dwivedi, S., Singh, M. 2013. Evaluation and correlation of serum glycoconjugates: protein bound hexoses, sialic acid and fucose in leukoplakia, oral sub mucous fibrosis and oral cancer. J. Nat. Sci. Biol. Med., 4: 122-125.

Bull, C., Stoel, M.A., den Brok, M.H., Adema, G.J. 2014. Sialic acids sweeten a tumor's life. Cancer Res., 74: 3199-3204.

Casper, R.F., Quesne, M., Rogers, I.M., Shirota, T., Jolivet, A., Milgrom, E., Savouret, J.F. 1999. Resveratrol has antagonist activity on the aryl hydrocarbon receptor: implications for prevention of dioxin toxicity. Mol Pharmacol., 56: 784-790.

Dische, L., Shettles, L.B. 1948. A specific color reaction of methylpentoses and a spectrophotometric micromethod for their determination. J. Biol. Chem., 175: 595-604.

Dodge, J.T., Mitchell, C., Hanahan, D.J. 1963. he preparation and chemical characteristics of hemoglobin-free ghosts of human erythrocytes.
Archives of Biochemistry and

Biophysics 100: 119-130.

Falholt, K., Lund, B., Falholt, W. 1973. An easy colorimetric method for routine determination of free fatty acids in the plasma. Clin. Chim. Acta, 46:105-111.

Fliesler, S.J., Keller, R.K. 1995. Metabolism of $[3 \mathrm{H}]$ farnesol to cholesterol and cholesterogenic intermediates in the living rat eye. Biochem. Biophys. Res. Commun., 210: 695-702.

Foster, L.V., Dunn, R.T. 1973. Stable reagent for determination of serum triglycerides by a colorimetric Hantzsch condensation method. Clin Chem., 19: 338-340.

Gaur, P., Mittal, M., Mohanti, B.K., Das, S.N. 2011. Functional genetic variants of TGF- $\beta 1$ and risk of tobacco-related oral carcinoma in high-risk Asian Indians. Oral Oncol., 47: 1117-1121.

Gokul Raj, K., Chidambaram, R., Varunkumar, K., Ravikumar, V., Pandi, M. 2015. Chemopreventive potential of fungal taxol against 7, 12dimethylbenz[a]anthracene induced mammary gland carcinogenesis in Sprague Dawley rats. Eur. J. Pharmacol., 767: 108-18.

Hail, N., Cortes, M., Drake, E.N., Spallholz, J.E. 2008. Cancer chemoprevention: a radical perspective. Free Radic. Biol. Med., 45: 97-110

Hynes, R.O. 2009. The extracellular matrix: Not just pretty fibrils. Sci., 326: 12161219

Isozaki, T., Ruth, J.H., Amin, M.A., Campbell, P.L., Tsou, P.S., Ha, C.M., Haines, G.K., Edhayan, G., Koch, A.E. 2014. Fucosyltransferase 1 mediates angiogenesis, cell adhesion and rheumatoid arthritis synovial tissue fibroblast proliferation. Arthritis Res. Ther., 28: 1-14.

Iwata, S., Saito, S., Kon-ya, K., Shizuri, Y., Ohizumi, Y. 2001. Novel marine- 
derived halogen-containing gramine analoguesinduce vasorelaxation in isolated rat aorta. Eur. J. Pharmacol., 432: 63-70.

Katopodis, N.N. 1980. Improved method to determine lipid bound sialic acid in plasma or serum. Res. Commun. Chem. Pathol. Pharmacol., 30: 171180.

Ke, S., Shi, L., Cao, X., Yang, Q., Liang, Y., Yang, Z. 2012. Heterocycle-functional gramine analogues: Solvent-and catalyst-free synthesis and their inhibition activities against cell proliferation. Eur. J. Med. Chem., 54: 248-254.

Kumar, S., Saxena, M., Srinivas, K., Singh, V.K. 2015. Fucose: A biomarker in grading of oral cancer. Natl. J. Maxillofac. Surg., 6: 176-179.

Lee, L.L., Lee, J.S., Waldman, S.D., Casper, R.F., Grynpas, M.D. 2002. Polycyclic aromatic hydrocarbons present in cigarette smoke cause bone loss in an ovariectomized rat model. Bone 30: 917-923.

Niebes, P. 1972. Determination of enzymes and degradation products of glycosaminoglycan metabolism in the serum of healthy and varicose subjects. Clin. Chim. Acta, 42:399408.

Parekh, A.C., Jung, D.H. 1970. Cholesterol determination with ferric acetateuranium acetate reagent and sulphuric acid ferrous sulphate reagents. Anal. Chem., 42:1423-1427.

Patel, P.S., Adhvaryu, S.G., Balar. D.B., Parikh, B.J, Shah, P.M. 1994.Clinical application of serum levels of sialic acid, fucose and seromucoid fraction as tumour markers in human leukemias. Anticancer Res., 14: 747751.

Quist, E.H. 1980. Regulation of erythrocyte membrane shape by calcium ion.
Biochem Biophys Res Commun 92: 631-637.

Rajkamal. G., Suresh, K., Sugunadevi, G., Vijayaanand, M.A., Rajalingam, K. 2010. Evaluation of chemopreventive effects of Thymoquinone on cell surface glycoconjugates and cytokeratin expression during DMBA induced hamster buccal pouch carcinogenesis. BMB Report 43: 664669.

Seales, E.C., Jurado, G.A., Brunson, B.A., Wakefield, J.K., Frost, A.R., Bellis, S.L. 2005. Hypersialylation of beta1 integrins, observed in colon adenocarcinoma, may contribute to cancer progression by upregulating cell motility. Cancer Res 65: 46454652.

Stowell, S.R., Ju, T., Cummings, R.D. 2015. Protein glycosylation in cancer. Annu Rev Pathol 10: 473-510.

Suresh, K., Manoharan, S., Panjamurthy, K., Senthil, N. 2007. Modifying effects of Annona squamosa on glycoconjugates levels in 7,12dimethylbenz(a)anthracene induced hamster buccal pouch carcinogenesis. J. Med. Sci., 7: 100-105.

Swierczynski, J., Hebanowska, A., Sledzinski, T. 2014. Role of abnormal lipid metabolism in development, progression, diagnosis and therapy of pancreatic cancer. World $J$ Gastroenterol., 20: 2279-2303.

Taqi, S.A.2012. Clinical evaluation of total and lipid bound sialic acid levels in oral precancer and oral cancer. Indian J Med Paediatr Oncol 33: 36-41.

Varki, N.M., Varki, A. 2007. Diversity in cell surface sialic acid presentations: implications for biology and disease. Laboratory Investigation 87: 851-857.

Wagner. M., Schmelz, K., Dorken, B., Tamm, I. 2008. Epigenetic and genetic analysis of the survivin promoter in 
acute myeloid leukemia. Leuk Res, 32:1054-1060.

Walz, G., Aruffo, A., Kolanus, W., Bevilacqua, M.1990. Seed B. Recognition by ELAM-1 of the sialylLe $\mathrm{X}$ determinant on myeloid and tumor cells. Sci., 250: 1132-1135.

Warren, L. 1959. The thiobarbituric acid assay of sialic acids. J. Biol. Chem., 234:1971-1975.
West, D.C., Hampson, I.N., Arnold, F. 1985. Angiogenesis induced by degradation products of hyaluronic acid. Sci., 228:1324-1326.

Zilversmit, D.B., Davis, A.K. 1950. Microdetermination of plasma phospholipids by trichloroacetic acid precipitation. J. Lab. Clin. Med., 35: 155-160.

\section{How to cite this article:}

Ramu Arun Kumar, Kathiresan Suresh, Ramadoss Hemavardhini and Nallu Anandhi. 2016. Protective Effects of Gramine on Cell Surface Integrity and Status of Lipid Profile during DMBA induced Oral Carcinogenesis. Int.J.Curr.Res.Aca.Rev.4(11): 8-17. doi: http://dx.doi.org/10.20546/ijcrar.2016.411.002 